\title{
Justice for Judges in Ukraine: Looking for Peace and Strong Judiciary Institutions in a Sustainable Society
}

\author{
By Mykola Rudenko ${ }^{1}$, Iryna Malinovska ${ }^{2}$, Serhij Kravtsov ${ }^{3}$
}

\begin{abstract}
Regarding the judiciary, the purification and lustration initiatives had been alleged as a beginning of a new stage of radical reformation, appreciated by European institutions. Therefore, in this article we will provide a detailed picture of the lustration of judges in Ukraine from the angle of its procedural guarantees as well as its legal nature; a special focus will be given to issues of efficiency of lustration restrictions, provided by the national legislation as well as its compliance within the European guidelines and Ukrainian Constitution. Lustration of judges will be analyzed regarding ordinary sanctions, enforced upon judges in case of committing disciplinary offences.
\end{abstract}

Keywords: judiciary, courts' reform, lustration of judges

\section{The Methods of the Research}

The research methodology is based on a combination of theoretical, methodological and practical levels of lustration research in the processes of modernization of the Ukrainian political system. Accordingly, in our research we will use the following groups of methods:

(a) methods of theoretical analysis are based on comparing academic concepts on lustration mechanisms in European countries;

(b) methods of empirical study are based on collection and processing of practical outputs of various models of lustration application on the example of Ukraine.

During the current scientific review, the following methods of theoretical analysis would be elaborated: 1) the historical method, based on specific features of lustration in the political system, will take into account the realities of the past, present and will project scenarios for the future; 2) the hermenentic method, which will contribute to the determination of the compliance of lustration models with the current social needs, values and interests; 3) the comparative method will allow to generalize the experience of lustration in Ukraine, as well as in Germany, Poland, Bulgaria, Albania, Czechoslovakia, and other European countries; 4) the structural-functional method will help clarify the structure and functions of the lustration procedure as a unique legal institution. Such instruments as analysis, synthesis, abstraction, idealization, generalization will contribute to the expansion of relevant facts existed in theoretical knowledge, as well as finding out new ways to target outlined goals and

| ${ }^{1}$ Doctor of Legal Sciences, Professor of Law, Professor of Law, Department of Constitutional Law, Faculty of Volodymyr Dahl East Ukrainian National University, Ukraine

${ }^{2} \mathrm{Ph}$. D. (Law), Assist. Prof. of Civil Law Department, Yaroslav Mudryi National Law University

${ }^{3} \mathrm{PhD}$ (Law), Associate Professor of Civil Procedure Department, Yaroslav Mudryi National Law University, 
objectives, including the synthesis of intermediate and final conclusions.

\section{The Relevant Literature on the Outlined Problem}

Undoubtedly, priority in the scientific exploration of lustration problems belongs to the foreign authors (R. David, L. Stan, N. Nedelski, H. Uesh, A. Opalinska, P. Gzhelyak, Ya. Volenskyy, P. Zhachek, J. Kholinskyy, P. Blazhek, G. Schwartz and others). Among domestic scientists, lustration issues were considered by V. Deinychenko, S. Denisyuk, N. Meninkova, A. Porayko, A. Rudenko, A. Sakhno, A. Stepanenko, J. Turchin, S. Shevchuk. It should be noted that most of the domestic investigations are journalistic in nature or devoted only to the certain aspects of the problem. Therefore, such demonstrates the lack of academic findings that would not only reveal the theoretical content of the lustration phenomenon. The other equally important development is to identify the features of its practical implementation as a factor of democratization of the Ukrainian political system, especially in the context of the modern transformation process after the events that took place in 2014. Thus, the vast majority of researches is limited to a historical and legal analysis of lustration processes in Eastern Europe (N.Ye. Minenkova, S. Karstadt, R. David), or is reduced to the simple analysis of the impact of the European lustration model on the Ukrainian legal institutions: criminal law and process (K.P. Zadoya), constitutional law (V. Knysh), the institute of public service (A. Poraiko), etc. In view of this, there are few theoretical developments on the revealing the lustration as a legal phenomenon. Therefore, in national legal doctrine there is no unified approach to the understanding the meaning of lustration, there is no common understanding of its teleological nature. In addition, it is not defined the place of the term that denotes aforesaid phenomenon in the conceptual-categorical apparatus. Consequently, it is important to analyze the origins of the lustration processes, find out the essence of the concept and identify the main directions of development and possible shortcomings in the lustration changes in presentday Ukrainian society.

\section{Lustration as a Legal Institute of a Modern and Open Society}

Based on the recognition, within the framework of this article, the authors will elaborate not purely political, but administerial guidelines, according to which persons from previous regime are prohibited from holding public office.

Lustration was one of the main requirements of Euromaidan. Ukrainian citizens had great expectations for reconciliation and a pressing need not only to renew authorities and regain confidence in them, but also to restructure the entire political system of the State. Nevertheless, according to the large-scale statistical research, a rather small group of judges (no more than $1 \%$ ) falls under the 'lustration', specifically those judges who adjudicated cases of the participants of the 'Maidan' events, which lasted from 21 November 2013 to 11 April 2014. Consequently, the confidence in the Ukrainian judicial system was significantly undermined ${ }^{1}$.

${ }^{1}$ S Prylutskyi, O Strieltsova ‘The Ukrainian Judiciary under 21st-Century Challenges’ (2020) 2/3(7) Access to Justice in Eastern Europe 78-99. 
Indeed, the interest in lustration is associated with the need for transition towards democracy and adherence to the principle of the rule of law. Lustration measures must comply with the rule of law principle and the doctrine of fundamental freedoms and the conceptual principles of democracy. Moreover, aforesaid measures must also be accompanied by certain guarantees that would make it impossible to use lustration as an instrument to settle political or personal scores with opponents. To a certain extent lustration can be represented as a peculiar national idea, specifically, of the founding core of the society that sought to be substantially transformed and reformed. At the same time, the experience of post-Soviet countries has shown that lustration could be used either as a means of political struggle, or as the possibility of power abuse. Under those circumstances, it is a viable threat to democratic transformations, since it leads to even greater stagnation of both the State and society, where corruption prevails instead of the rule of law, oligarchy prevails instead of human rights, and a totalitarian regime reigns instead of a democratic order. According to the American researcher of the lustration process G. Schwartz,

'the proponents of the lustration also often do not consider the correspondence between guilt and punishment. ${ }^{2}$

In order to prevent these negative phenomena, the basic principles and mechanisms for carrying out lustration were stipulated in several international legal instruments. In particular, in 1996, the Parliamentary Assembly of the Council of Europe has adopted Resolution No 1096 'Measures to dismantle the heritage of former communist totalitarian systems'3 and 'Guidelines for Ensuring That Lustration Laws and Similar Administrative Measures Comply with the Requirements of The State that Is Based on the Rule of Law,'4 that are compulsory for consideration in member states of the Council of Europe.

In terms of Ukrainian lawyer Valeryi Andreevskyi, lustration can be defined as 'a whole series of political and legal measures, aimed to diminish devastating consequences of the previous, hostile to man and people, regime. ${ }^{5}$ According to German researcher Susanne Karstedt, lustration can include

'two types of public prosecution: first of all, that could be criminal prosecutions of the elite representatives and government officials, who had undertaken highest posts in the state administration of the past regime, and secondly, it could be procedures of massive investigations against those, who had voluntarily cooperated with the past regime,

2 G Schwartz, Postanovlenija novyh konstitucionnyh sudov v stranah Central'noj Evropy otnositel'no ljustracii' ['Regulations of New Constitutional Courts in Central European Countries regarding Lustration'] (Conference on Constitutional Court, Warsaw 1994) < https://nsarchive.gwu.edu/rus/text_files/EastUropeProblems/1995-4344/1995-43-44\%20(189-203).pdf > accessed 25 October 2020.

3 Parliamentary Assembly of the Council of Europe, Resolution 'On Measures to Dismantle Communist Totalitarian Systems'1096 (1996) <http://assembly.coe.int/nw/xml/XRef/Xref-XML2HTML-en.asp?fileid=16507> accessed 25 October 2020.

4 Parliamentary Assembly of the Council of Europe, 'Guidelines to ensure that lustration laws and similar administrative measures comply with the requirements of the State that is based on the rule of law' in Measures to dismantle the heritage of former communist totalitarian systems 7568 (1996) < http://assembly.coe.int/nw/xml/xref/x2h-xrefviewhtml.asp?fileid=7506\&lang=en $>$ accessed 25 October 2020.

${ }^{5}$ Chto takoye lyustratsiya? Yesli yeye provodit' nepravil'no, ona pererastayet $\mathrm{v}$ repressii. Mezhdunarodnyy opyt ['What is Lustration? If it is Carried out Incorrectly, it Grows into Repression. International Experience'] (Hroniky $i$ Kommentarii, 12 March 2014), <https://operkor.wordpress.com/2014/03/12/> accessed 25 October 2020. 
including party activists or state agency employees of middle and lower rank in the bureaucratic hierarchy (such as police, security services). ${ }^{6}$

This type of lustration, among other prospects, is aimed at restoring the initial social trust in public institutions, which had previously been disqualified by numerous violations of human rights. According to the legal opinion of the High Council of Justice, enshrined in its decision No 1204/0/15-15, delivered on 24 December 2015,

'negative consequences [in sense of limitations, provided by the Law of Ukraine "On Purification of Government"], that must be imposed [upon a judge], cannot be regarded as legal liability measures due to their legal genesis, but shall rather be viewed as exceptional remedies, aimed at improving the system of state governance as a whole and the functioning of the judiciary in particular.'

The same legal position has been delivered in a decision of the Supreme Court Grand Chamber in the proceedings No 800/186/17 of 31 January 2019, where the Court confirmed the legality of the dismissal of the Head of the Higher Qualification Commission of Ukraine Igor Samsin, to whom the Law of Ukraine 'On Purification of Government' had been applied. The former Head of the Higher Council of Justice was not successful in the national courts appealing his dismissal from this post that he had held from March 2010 till May 2013.7 Our research shows that judges, who had been automatically removed from their posts under the Law of Ukraine 'On Purification of Government', did not win their numerous court claims at national level, although rare successful claims of other categories of fired civil servants were recorded.

Upon jeopardizing systems of lustration in Eastern and Central Europe, Laisve Linkute comes to the conclusion that it is not possible to devise a fair system of lustration, because it would still be unfair at some point.' ${ }^{8}$ This point of view is arguable, unless we refer to the universal concept of justice, elaborated centuries ago in ancient Greece. As AntonHermann Chroust and David L. Osborn reflect on Aristotle's conception of justice, "While there exists but one universal concept of the "just," its implications can be fully understood only if we approach it simultaneously from two directions - from the direction of moral Justice and from the direction of the principle of Equality. The "just" is the same in both instances, although the particular forms in which Justice is administered or formulated - the "modes" of Justice - are separate."

In other words, any system of lustration, even elaborated and implemented in full compliance with European guidelines, would not be accepted as fair or perfect by everybody; there would be opponents as well as strong supporters of this concept. In our opinion,

'S Karstedt, 'Coming to Terms with the Past in Germany after 1945 and 1989: Public Judgements on Procedures and Justice' (1998) 20 Law and Policy.

7 Decision of High Council of Justice No 1204/0/15-15 (24 December 2015) $<$ http://www.vru.gov.ua/act_list> accessed 25 October 2020; Ruling of the Supreme Court Grand Chamber in the proceedings No 800/186/17 (31 January 2019) <http://www.reyestr.court.gov.ua/Review/76822787> accessed 25 October 2020; Ruling of the Supreme Court Grand Chamber in the proceedings No 800/235/17 (21 May 2020) <http://www.reyestr.court.gov.ua/Review/758764379> accessed 25 October 2020.

${ }^{8} \mathrm{~L}$ Linkute, Is it Possible to Devise a Fair System of Lustration?' (Loughborough University, 2011) <http://www.e-ir.info/2012/06/01/is-it-possible-to-devise-a-fair-system-of-lustration> accessed 25 October 2020 .

9 A H Chroust, D L Osborn, 'Aristotle's Conception of Justice', (1942) 17(2) Notre Dame Law Review 129-143 <http://scholarship.law.nd.edu/ndlr/vol17/iss2/2> accessed 25 October 2019. 
national background and regional traditions should be seriously regarded when formulating a recipe for the purification of the judiciary. If this demand is ignored, most of the efforts aimed at launching a fair system of justice, would be declared useless or inefficient.

Therefore, in some countries lustration has not acquired proper public approval or has been condemned at official level. However, lustration restrictions have been more typically criticized or jeopardized, while acknowledged on the whole. By addressing policy papers, regarding European experiences of lustration, ${ }^{10}$ we can identify some features of lustration in Eastern and Central European countries:

1) In most of these countries, lustration measures were launched to overcome the negative effects of the communist regimes upon their failure; these regulations put a special focus on detecting and punishing those who had contributed to human rights violations or collaborated with secret services. For example, in Poland lustration legislation was adopted in the period of 1999-2006 years and put an obligation upon all public servants to undergo through lustration procedures (this list included judges) ${ }^{11}$. The Polish Institute of National Remembrance had been entitled to administer lustration procedures. ${ }^{12}$ Polish civil servants were obliged to file an official declaration, in which they unveiled the facts of their former collaboration with the Communist security institutions. The content of those declarations was verified by the Public Interest Spokesman. This public official was empowered to send an indictment to the lustration court, which would establish the truth. A civil servant, found guilty of submitting untrue information, would be dismissed from his/ her office for a ten year term. ${ }^{13}$ In the Czech Republic, two lustration laws were adopted in 1991, according to which representatives of the former parties' nomenclature, officials of the security service and other supporters of the communist regime were deprived of the right to take up supervisory positions. Then up to 140, 000 people were forced to undergo vetting procedures. Each candidate for government positions was checked for facts of previous cooperation with the state security service agents. ${ }^{14}$

2) In almost all of these countries, the introduction of lustration procedures caused the

${ }^{10}$ We base our finding on the results of reviewing such sources: K Khlabystova,I Instytut lyustratsiyi: konstytutsiyno-pravovi zasady rehulyuvannya ta vdoskonalennya: dysertatsiya na zdobuttya naukovoho stupenya kandydat ayurydychnykh nauk' ['Institute of Lustration: Constitutional and Legal Principles of its Regulating and Improving'] (PhD Thesis, Kyiv University of tourism, economics and law; National Academy of Internal Affairs, 2017); V Dvořáková, A Milardović (eds.), Lustration and Consolidation of Democracy and the Rule of Law in Central and Eastern Europe (Political Science Research Centre 2007, Book 5).

${ }^{11}$ See more in G Borkowski, O Sovgyria, 'Current Judicial Reform in Ukraine and in Poland: Constitutional and European Legal Aspect in the Context of Independent Judiciary' (2019) No 2 (3) Access to Justice in Eastern Europe 5-35.

${ }^{12} \mathrm{~A}$ Ploshchins'ka, 'Lyustratsiya v Yevropeys'kykh krayinakh' ['Lustration in European Countries'] (Blog of Resursnyy Center Gurt, 2016) <http://gurt.org.ua/blogs/Анастасія\%20ПАощинська/1685/> accessed 25 October 2020.

${ }^{13} \mathrm{~K}$ Williams, A Szczerbia, B Fowler, 'Explaining Lustration in Eastern Europe: 'A Post-communist politics approach' (2003) 62 Sussex European Institute Working Paper 17.

${ }^{14}$ I Lavrynenko, 'Yakshcho nepravyl'no provodyty lyustratsiyu, vona pererostaye v represiyi' [If Lustration is Misconducted, it Turns into Repression'] (2014) 6 Racurs <http://racurs.ua/ua/470-yakscho-nepravylnoprovodyty-lustraciu-vona-pererostaie-v-represiyi> accessed 25 October 2020; O Sahno, 'Shcho take lyustratsiya? Z dosvidu ukrayinkolyshn'oho sotstaboru' ['What is lustration? From the Experience of Countries of the Former Socialist Camp'] (Web-site of the National Lustration Committee, 5 May 2009) <http://www.lustration.com.ua/category/statti/> accessed 10 June 2019. 
resistance of those they targeted, or of some special social groups. For instance, according to Radoslaw Peterman from the Polish Institute of National Remembrance, judges were very active in opposing lustration of their colleagues, which caused a chilling effect on the results of judicial purification. ${ }^{15}$ In some countries social resistance to vetting initiatives lead to their failure. According to Canadian researcher Maria Popova, 'In Serbia, the democratic opposition to the regime of Slobodan Milosevic tried to lustrate the judiciary, but was immediately defeated, because the judiciary opposed this attempt actively and effectively. Judges sabotaged every step of the reform process. In the end, the ruling coalition collapsed and many dismissed judges were restored to their positions after appealing their dismissals in courts. For a while, the judiciary in Serbia maintained its political independence from governmental officials. However, judicial corruption currently remains a serious problem in Serbia.'16

3) In a number of countries in Eastern and Central Europe some provisions of lustration regulations or the overall lustration laws were declared unconstitutional by national courts. In particular, some provisions of lustration legislations were revoked by constitutional courts in Hungary, Slovakia, Bulgaria, Romania, Albania, Lithuania. In Croatia, lustration measures have not been introduced due to the alleged unconstitutionality of lustration laws. ${ }^{17}$

4) Out of Eastern and Central European countries, where lustration measures were executed, in Bosnia and Herzegovina special mechanisms of vetting judges, similar to the ones in Ukraine, were launched. In most other countries, judges appeared in a long row of state officials, subject to vetting procedures, however, we have not found any special lustration laws - analogues to the Law 'On Restoring Trust Into Judicial Power in Ukraine.' This cannot be regarded positively or negatively, it rather reflects national circumstances and traditions. According to Jakob Finci, in Bosnia and Herzegovina

'laws, adopted in May 2000, established commissions comprising Bosnian judges and prosecutors who assessed the performance of their peers over a period of eighteen months. But the process was never adequately resourced and ended in failure. The vast majority of complaints were dismissed as unsubstantiated. In late 2001, the Independent Judicial Commission, the lead agency on judicial reform, developed a new strategy for reform. It aimed at reducing the number of judges and making the judicial and prosecutorial services more ethnically diverse through a formal re-application and appointment process...'18.

Thus, in international law, lustration is considered as one of the tools essential for transitional justice, which is used to protect new democratic states from threats associated with those individuals who have been closely linked with the previous totalitarian regimes. That is why it aims at prevention of the return of such regimes via the prohibition of the officials, representing the former regimes to occupy influential government positions in

${ }^{15} \mathrm{~J}$ Woleński, Lustracjaja koz̨wierciadto (Universitas2007).

${ }^{16} \mathrm{M}$ Popova, 'Sudovi reformy: yevropeys'kyy dosvid ta ukrayins'ki realiyi' ['Judicial Reforms: European Experience and Ukrainian Realities'], (Evpopeys'ka Pravda, 17 December 2014) <https://www.eurointegration.com.ua/experts/2014/12/17/7028850/> accessed 25 October 2020.

${ }^{17}$ Shevchuk (n 34); Khlabystova(n 38).

${ }^{18} \mathrm{~J}$ Finci, 'Lustration and Vetting Process in Bosnia and Herzegovina', in V Dvořáková, A Milardović (eds), Lustration and Consolidation of Democracy and the Rule of Law in Central and Eastern Europe (Political Science Research Centre 2007, Book 5) 219-220. 
the country, after such regime has been changed.

According to the Ukrainian researcher S. Balan, one of main consequences of political responsibility is

'depriving of the legitimate opportunity to execute one's plans either at the current moment (for a politician) or in the future (for opposition politicians).... Political responsibility does not demand a concrete basis to be applied to its subject; it could be a result of political sympathies or antipathies. ... Political responsibility does not demand guilt as its obligatory prerequisite, while political sanctions can be applied without addressing due process procedures and safeguarding fair trial standards. ${ }^{19}$

In the case STRELETZ, KESSLER AND KRENZ v. GERMANY the European Court of Human Rights stated that

'... it is legitimate for a State governed by the rule of law to bring criminal proceedings against persons who have committed crimes under a former regime; similarly, the courts of such a State, having taken the place of those which existed previously, cannot be criticized for applying and interpreting the legal provisions in force at the material time in the light of the principles governing a State subject to the rule of law (para. 81).'20

In case we regard lustration as a legal instrument of defending democracy, we should reconcile the concept that denies bringing judges to political liability, and the European standard of lustration as a legal procedure with political background.

Similarly, the Law 'On Restoring Trust into Judicial Power in Ukraine' No 1188-VII introduced automatic dismissal of all the Presidents of general jurisdiction courts. Such a removal was the exclusive act of political expediency, because: (a) Presidents of courts were punished for the fact of holding a particular position during the reign of one of the Presidents of Ukraine (Victor Yanukovych); (b) dismissal of judges holding administrative posts in courts from their leading positions was done outside the fair legal procedure and without any possibilities to appeal this fact. It could have been predicted that such dismissals would be condemned by the European Court of Human Rights as incompatible with the Council of Europe Standards, unless the legislation in Ukraine was changed in the course of judicial reform of 2016 and a mechanism of restoring the dismissed Presidents existed. However, we do not have information on judges, who would have appealed those dismissals, unlike those, disciplined under other vetting procedures, in particular, according to the decisions of the High Council of Justice. According to Ivan Lishyna, the Government Representative in the cases of the European Court of Human Rights, 'few dozens of officials, who had been vetted, filed their complaints to the European Court of Human Rights, but the perspectives of those judicial claims are vague, considering the ruling of the Court in the case "Kulykov and 17 others against Ukraine". ${ }^{21}$ In

19 S Balan, 'Spivvidnoshennya politychnoyi ta konstytutsiyno-pravovoyi vidpovidal'nosti u zdiysnenni derzhavnoyi vlady' ['Value of Political and Constitutional (Legal) Responsibility in the Implementation of State Power'] (PhD Thesis, Institute of State and Law named after V. M. Koretskiy 2007).

${ }^{20}$ Streletz, Kessler and Krenz v. Germany (App Nos 34044/96, 35532/97 and 44801/98) ECHR 22 March 2001, <https://hudoc.echr.coe.int/tur\#\{\%22itemid\%22:[\%22001-59353\%22]\}> accessed 25 October 2020.

${ }^{21}$ I Lischina, 'Upovnovazhenyy u spravakh YESPL: do mene khodyat' lyustrovani chynovnyky' ['Commissioner for ECHR Cases: I have to Deal with Complaints of Lustrated Officials'] (Ukrayins'ki Natsional'ni Novyny Informatsiyne Abentstvo, 26 January 2017) <www.unn.com.ua/uk/news/1638747upovnovazheniy-u-spravakh-yespl-do-mene-khodyat-lyustrovani-chinovniki> accessed 10 October 2020. 
this case the Court rendered just satisfactions to a number of disciplined judges, but did not recommend restoring them in their offices, explaining it in such a way:

'... at the present time a full-fledged judicial reform is taking place in Ukraine which includes constitutional and further legislative amendments, as well as institutional changes. Against this background, the Court is not in a position to assess the effectiveness at the moment of the procedure for the reopening of the domestic proceedings, if requested by the applicants. However, given the scope and the circumstances of the present applications, it cannot be concluded that this substantially new background renders the relevant domestic procedures prima facie futile and useless. The Court does not therefore follow the approach, taken in Oleksandr Volkov as to the indication of an individual measure and dismisses the relevant request»'(para. 148). ${ }^{22}$

Considering the further progress that Ukraine has demonstrated in reforming judiciary during 2017-2018, it is hard to assess the perspectives of the numerous applications of judges, awaiting their hearings in Strasbourg. They could have become even more vague after the Constitutional Court of Ukraine would render its highly anticipated decision by the society on the issue of lustration.

\section{Conclusions}

However, some social groups are not revealing deep satisfaction of the vetting procedures' results, reporting its selectivity and vagueness. In spite of critical comments, lustration of judges and further judicial reform in Ukraine demonstrate compliance with basic European recommendations and would be further recorded and scrutinized by historians and political scientists. In this vein, from the legal perspective, lustration is constituted as a form of withdrawal of officials' status from persons who violate constitutional principles, in particular, enshrined in art. 8 of the Constitution of Ukraine, upholding the principle of the rule of law. The international conclusions and recommendations of well-known institutions, with reference to the recommendations of the PACE, and the conclusions of the Venice Commission are significantly important in the lustration mechanism. In its opinion on the Ukrainian Law on lustration, the Venice Commission has emphasized that the process of lustration, despite its political implications, should take place exclusively within the legal framework, thus in accordance with the constitutional provisions and European standards.

\section{References}

G Schwartz, Postanovlenija novyh konstitucionnyh sudov v stranah Central'noj Evropy otnositel'no ljustracii' ['Regulations of New Constitutional Courts in Central European Countries regarding Lustration'] (Conference on Constitutional Court, Warsaw 1994) < https://nsarchive.gwu.edu/rus/text_files /EastUropeProblems/1995-43-44/1995-43-44\%20(189-203).pdf > accessed 25 October 2020.

Parliamentary Assembly of the Council of Europe, Resolution 'On Measures to Dismantle Communist Totalitarian Systems'1096 (1996) < http://assembly.coe.int/nw/xml/XRef/Xref-XML2HTML-en.asp?fileid=16507> accessed 25 October 2020 .

22 Kulikov and 17 Others $v$ Ukraine (App No 5114/09) ECHR 19 January 2017 http://www.scourt.gov.ua/clients/vsu/vsu.nsf/7864c accessed 19 October 2020. 
Parliamentary Assembly of the Council of Europe, 'Guidelines to ensure that lustration laws and similar administrative measures comply with the requirements of the State that is based on the rule of law' in Measures to dismantle the beritage of former communist totalitarian systems 7568 (1996) $<$ http://assembly.coe.int $/ \mathrm{nw} / \mathrm{xml} / \mathrm{xref} / \mathrm{x} 2 \mathrm{~h}$-xref-viewhtml.asp?fileid $=7506 \& l a n g=$ en $>$ accessed 25 October 2020.

'Chto takoye lyustratsiya? Yesli yeye provodit' nepravil'no, ona pererastayet $\mathrm{v}$ repressii. Mezhdunarodnyy opyt ['What is Lustration? If it is Carried out Incorrectly, it Grows into Repression. International Experience'] (Hroniky $i$ Kommentarii, 12 March 2014), $<$ https://operkor.wordpress.com/2014/03/12/> accessed 25 October 2020.

S Karstedt, 'Coming to Terms with the Past in Germany after 1945 and 1989: Public Judgements on Procedures and Justice' (1998) 20 Law and Policy.

Decision of High Council of Justice No 1204/0/15-15 (24 December 2015) $<$ http://www.vru.gov.ua/act list> accessed 25 October 2020; Ruling of the Supreme Court Grand Chamber in the proceedings No 800/186/17 (31 January 2019) $<$ http://www.reyestr.court.gov.ua/Review/76822787> accessed 25 October 2020; Ruling of the Supreme Court Grand Chamber in the proceedings No 800/235/17 (21 May 2020) <http://www.reyestr.court.gov.ua/Review/758764379> accessed 25 October 2020.

L Linkute, Is it Possible to Devise a Fair System of Lustration?' (Loughborough University, 2011) $<$ http://www.e-ir.info/2012/06/01/is-it-possible-to-devise-a-fair-system-of-lustration $>$ accessed 25 October 2020.

S Prylutskyi, O Strieltsova ‘The Ukrainian Judiciary under 21st-Century Challenges’ (2020) 2/3(7) Access to Justice in Eastern Europe 78-99.

A H Chroust, D L Osborn, 'Aristotle's Conception of Justice', (1942) 17(2) Notre Dame Law Review 129-143 $<$ http://scholarship.law.nd.edu/ndlr/vol17/iss2/2> accessed 25 October 2019.

We base our finding on the results of reviewing such sources: $\mathrm{K}$ Khlabystova,I Instytut lyustratsiyi: konstytutsiyno-pravovi zasady rehulyuvannya ta vdoskonalennya: dysertatsiya na zdobuttya naukovoho stupenya kandydat ayurydychnykh nauk' ['Institute of Lustration: Constitutional and Legal Principles of its Regulating and Improving'] ( $\mathrm{PhD}$ Thesis, Kyiv University of tourism, economics and law; National Academy of Internal Affairs, 2017); V Dvořáková, A Milardović (eds.), Lustration and Consolidation of Democracy and the Rule of Law in Central and Eastern Europe (Political Science Research Centre 2007, Book 5).

A Ploshchins'ka, 'Lyustratsiya v Yevropeys'kykh krayinakh' ['Lustration in European Countries'] (Blog of Resursnyy Center Gurt, 2016) <http://gurt.org.ua/blogs/Анастасія\%20Площинська/1685/> accessed 25 October 2020.

K Williams, A Szczerbia, B Fowler, 'Explaining Lustration in Eastern Europe: 'A Post-communist politics approach' (2003) 62 Sussex European Institute Working Paper 17.

G Borkowski, O Sovgyria, 'Current Judicial Reform in Ukraine and in Poland: Constitutional and European Legal Aspect in the Context of Independent Judiciary' (2019) No 2 (3) Access to Justice in Eastern Europe 5-35.

I Lavrynenko, 'Yakshcho nepravyl'no provodyty lyustratsiyu, vona pererostaye v represiyi' ['If Lustration is Misconducted, it Turns into Repression'] (2014) 6 Racurs < http://racurs.ua/ua/470-yakschonepravylno-provodyty-lustraciu-vona-pererostaie-v-represiyi> accessed 25 October 2020; O Sahno, 'Shcho take lyustratsiya? Z dosvidu ukrayinkolyshn'oho sotstaboru' ['What is lustration? From the Experience of Countries of the Former Socialist Camp'] (Web-site of the National Lustration Committee, 5 May 2009) < http://www.lustration.com.ua/category/statti/> accessed 10 June 2019.

J Woleński, Lustracjaja kozpinierciadto (Universitas2007).

M Popova, 'Sudovi reformy: yevropeys'kyy dosvid ta ukrayins'ki realiyi' ['Judicial Reforms: European Experience and Ukrainian Realities'], (Evpopeys'ka Pravda, 17 December 2014) $<$ https://www.eurointegration.com.ua/experts/2014/12/17/7028850/> accessed 25 October 2020.

Shevchuk (n 34); Khlabystova(n 38).

$\mathrm{J}$ Finci, 'Lustration and Vetting Process in Bosnia and Herzegovina', in V Dvořáková, A Milardović (eds), Lustration and Consolidation of Democracy and the Rule of Law in Central and Eastern Europe (Political Science Research Centre 2007, Book 5) 219-220. 
S Balan, 'Spivvidnoshennya politychnoyi ta konstytutsiyno-pravovoyi vidpovidal'nosti u zdiysnenni derzhavnoyi vlady' ['Value of Political and Constitutional (Legal) Responsibility in the Implementation of State Power'] (PhD Thesis, Institute of State and Law named after V. M. Koretskiy 2007).

Streletz, Kessler and Krenz v. Germany (App Nos 34044/96, 35532/97 and 44801/98) ECHR 22 March 2001, $<$ https://hudoc.echr.coe.int/tur\#\{\%22itemid\%22:[\%22001-59353\%22]\}> accessed 25 October 2020.

I Lischina, 'Upovnovazhenyy u spravakh YESPL: do mene khodyat' lyustrovani chynovnyky' ['Commissioner for ECHR Cases: I have to Deal with Complaints of Lustrated Officials'] (Ukrayins'ki Natsional'ni Novyny Informatsiyne Ahentstvo, 26 January 2017) <www.unn.com.ua/uk/news/1638747upovnovazheniy-u-spravakh-yespl-do-mene-khodyat-lyustrovani-chinovniki> accessed 10 October 2020.

Kulikov and 17 Others $v$ Ukraine (App No 5114/09) ECHR 19 January 2017 $<$ http://www.scourt.gov.ua/clients/vsu/vsu.nsf/7864c $>$ accessed 19 October 2020. 